\title{
Ties That Endure
}

To many radical lesbians who have approached the question of motherhood in the popular feminist litcrature, the term "family" refers to past experience-the backgrounds, socialization, and limitations our particular family histories impose on us. The poet Jan Clausen puts it this way: "Besides being aware of the parenting experience of other generations of lesbians, I think that before we speak of creating a parenting community, we must examine how our individual ideas about being parents, and our daily experience of living with children, differ according to our identities and backgrounds-the specific oppression we face and the specific strengths we have that grow out of our memories of the people who raised us."1

Kinship is of special interest to lesbian mothers because it provides a specific instance of the patrjarchal ideology from which they must separate themselves. Lesbians may see their families of origin as influential in the formation of their own families, but more often than not they construe that foundation as something to work against rather than as a source of ongoing meaning and validity. Most popular feminist work treats the family of origin as the place where children are socialized into heterosexuality and unequal gender roles-as the primary source of the "compulsory heterosexuality" to which Adrienne Rich alerted us. ${ }^{2}$

Most writers in this tradition assume that lesbian mothers differ significantly, and in positive ways, from other mothers: "As lesbian parents even more so than simply as lesbian women, I bclicve we are all fundamentally outlaws," writes Jan Clausen. "Like open, unashamed lesbian and gay sexuality, our chosen lesbian families call 
into question some tcribly basic assumptions about who's important to whom, and why." 3 Lesbian writers who outline stratcgies for dealing with the stresses and strains of parenthood use "family" to connote the chosen families of lesbians and see "the [Icsbian] community" as the potential source of support on many levels, functioning in essence as an extended family. They view lesbian families as explicitly political in that these families demand the redefinition of emotions and behaviors that patriarchy has confined to the traditional family.

Andrea Canaan asks, "How can I honor the commitment of friends, of loved ones, of my comother and others who hold me, who comfort me, who hold children dear and necessary to their own survival-they who understand that loving women means loving all the women we were, could have been, may become, and are becoming, including the mothers who bore us and the children we once wcrc?"4 Another lesbian mother writes: "As lesbians, who are automatically placed on the fringe of society by the choice of our lives, we can bring to parenting and to young children the positive aspects of being on that fringe- of possibility instead of control, acceptance instead of rejection, diversity instead of commercial homogeneity, and, yes, importantly, a world of many families in changing and varied forms, not limited by the term traditional."s

The tone of much Icsbian feminist popular writing, then, has adopted the language of sistcrhood that pervaded feminist discourse in the late 1960 s and early 1970 s, building on it to generate a series of assumptions about how important ties are constituted. Probably the first assumption is that lesbianism is a more central feature of the identity than any other, with the possible exception of femaleness. All women, and especially all lesbians, share basic life experiences and encounters in the domain of sexual politics; these common experiences eclipse ties based on kinship, work, social status, ethnicity, or geography. This literature rarely discusses the relationships lesbians establish or continuc with their parents, though the absence of discussion of these ties suggests that parents are unlikely to bc supportivc of one's choice to be a lesbian (conceived as a largely political choice), and that in any case their support is unimportant because they have little to offer to one whose life centers on being a lesbian.

This perspective is characteristic as well of the small body of social 
science scholarship on lesbians. Susan Kricger's meticulous ethnography of a lesbian community, The Mirror Dance, for example, devotes a single chapter to "mothers and children." Here Krieger reports the kinds of concerns common to lesbian mothers: that their children may suffer ostracism, that they may be vulnerable to child custody litigation, that their children might not feel comfortable with their lesbian identities or with their lesbian friends. But this chapter, like later ones on "the outside world" of relations with co-workers, relatives, and "straight society," segregates these elements of lesbians" lives from what seems to be the more authentic center provided by the lesbian-feminist community. The lesbian community is thus presented as a bounded, independent social world, not unlike a smallscale tribal society.

Barbara Ponse's Identities in the Lesbian World, reveals the pathways women travel in the course of "becoming" lesbians and explores the issues of passing and disclosure in the contexts where secrecy produces its most elaborate configurations. Not surprisingly, the workplace and the family emerge as the sites where disclosure raises the most problems. But Ponse treats these contexts, without apparent question, as outside the "gay group," implying that the meanings lesbians construct for their identities are located only within the "lesbian subculture."

Even the early work of John Gagnon and William Simon, which exhorted readers to remember that the life experience of lesbians is fundamentally similar to that of other women, particularly with respect to patterns of sexual initiation, tends to downplay lesbians' family ties and virtually ignores the roles many lesbians play as mothers. ${ }^{6}$

Kath Weston's Families We Choose is perhaps the only significant contribution to gay/lesbian scholarship that attempts to document fully the relationships between homosexuals of both genders and their families of origin. She describes the conflicts gay men and lesbians have with their families, and responses of "straight families" to a child's homosexuality which range from general acceptance through limited toleration to outright and permanent rejection. Even though the responses vary, however, gays' and lesbians' narratives about their blood relatives tend to focus on fear, anxiety, and displace- 


\section{[78] Lesbian Mothers}

ment, and on the family as the place where they are nost likely to experience painful homophobia. Weston documents the formation of "families we choose" or "gay families," constructed from friendship networks and assuming many of the functions traditionally expected of relatives. Though these chosen families are not strictly substitutes for ties with blood kin and nay exist even when ties with relatives have not been severed, they do serve to mark the limited power of biologically defined ties and to establish choice as an element in the maintenance of kinship links.

Intercstingly, gays and lesbians still use kinship imagery when they speak of their chosen fanilies and often compare them with their "straight families." Fundamental notions of what one expects from one's family-unconditional loyalty, for example-still prevail. That is, while chosen familics appear to constitute instances of cultural creation, they may also be seen as adaptations of existing cultural forms, transported and adjusted to fit specific conditions. The assumptions that underlie them are the old assumptions about family ties; Weston's informants seem to be unwilling to abandon these cxpcctations for totally new ones that might correspond more closely to their lived experience.

I had assumcd that lesbian mothers would form and sustain such ties very differently from heterosexual single mothers-that their networks would consist of (mainly lesbian) friends and that heterosexual mothers' networks would include many more relatives. Lesbian mothers, I reasoned, would be cast out of or voluntarily exiled from their families of origin and therefore would be likely to construct innovative fictive kin relationships to replace then. As I spoke with mothers, however, it becane clear that the importance of kinship ties for lesbian mothers reflected less a process of culture building than the continuity of kinship systens also available to heterosexual single mothers.

\section{The Importance of Kinship Ties}

As I questioned my informants about the practical challenges of single motherhood in an cffort to learn how they form and maintain 
their social networks and how they solve specific kinds of problems, consistent patterns began to emerge. Both lesbian and heterosexual mothers reported that they received assistance from their familiesemergency loans, money to make the down payment on a house, financial advice, car and home repairs, a place to live for little or no rent, money to pay for their children's music lessons and braces for their tecth, regular or emergency baby-sitting or child care, meals, transportation.

But the links with kin that both lesbian and heterosexual mothers described are more than just the best means to manage a variety of practical difficulties. These instrumental ties are located in a dense intersection of affective bonds. Ties with kin, especially with one's parents-the grandparents of one's child-represent a kind of wellbeing, a solid "family" context in which a child can develop securely. Thus the emotional bonds tend to overshadow the practical aid; the assistance that families provide serves to demonstrate the vigor of the kin connection, a benefit that not infrequently outweighs the value of the help received.

Eileen Sullivan and Wendy Gardner, adoptive mothers of two preschool children, have an arrangement with Wendy's motherGrammy to the children-for child care and evening baby-sitting. They are affluent professionals and could easily afford to pay for high-quality day care, but they prefer to kecp the regular care a family matter. Eileen, the children's legal mother, is open with her own parents about her situation, but as they live in another part of the country, their support is limited to friendly letters (with inquiries about Wendy) and gifts for the children. Eileen explained:

I think I'd like to have [my parents] closer so that there wonld be more intimacy. ... I feet so good about my relationship with my family I really do wish we were closer so we could spend more time together. . . There's something about having family around, like on holidays and stuff that I think is real special.

Here Eileen's concern is more with the affective dimension of kinship than with financial assistance. She and Wendy have savings and investments and are unlikely to face a financial situation that they 
would not be able to manage on their own. But family is a positive good, in her vicw, something that should be nurtured and supported, and that gives form and solidity to children's development.

Lesbian mothers are no less likely than heterosexual mothers to regard their parents as the most appropriate source of financial and practical assistance in a varicty of situations. Even when some strain has developed in relation to their sexual orientation, lesbian mothers still say that they look first to their families when they need basic support. In fact, mothers who do not go to their families for assistance are likely to fecl that they must explain their reluctance or inability to do so. Most such explanations are financial: the parents or other family members are not able to help because of financial limitations or other critical demands made on their resources.

When Theresa Baldocchi describes her parents, who live in Detroit, she emphasizes their poverty and frequently mentions of the many difficultics they have survived over the years. Her relationship with them centers on highly emotional weckly telephone calls and occasional visits, which Theresa (a successful professional) pays for. She sces herself as sharing her most scrious problems with them, but at the same time she is careful to protect them from any information she thinks might distress them-such as her Iesbianism. She thinks her parents suspect, but she has not actually told them directly because she fears this is the sort of news that would upset them. At the same time, although their ability to do concrete things for her is limited by both their low income and their geographical distance, Theresa says their relationship is so solid that she can ask for "anything." Her parents enclose a $\$ 10$ bill in nearly all their letters to her, "so they can fecl they are sending money." Since Theresa's income far exceeds of her parents', she sces the bills as a sign of their unconditional support.

If I call them and need support, they're real good. They're real good for me. Sometimes I'm real down, and I feel like here I am, living this dual life, and it's not fair-I can't have a lover, and I really want someone to spend my life with. . . I just want to meet that perfect woman and run off into the sunset with her. And here I am stuck with this kid and this ex-husband that hangs around all 
the time. And then they call. And it's like, God, how can I complain about my life? Look at them-they've been through so much and they've got so much spirit. They always say we love you so much.

Other women shrink from the looking to their parents for assistance out of a desire not to ask anyone for help; these mothcrs cmphasize their ability to resolve unexpected crises through thcir own cfforts, taking pride in their success in meeting their own needs and planning for the future.

Thus disputes over lifestyle very seldom change fundamental assumptions about the proper role of the family of origin as support in times of trouble. Not that lesbians have no friction with their families over their sexual orientation; such conflict can be intensc and acrimonious. But fundamental understandings about the meaning of family are rarely threatened by these disputes; rather, disputes are seen as undermining family ties as they ought to be.

Lesbianism does not seem to have disrupted some family ties at all. For women in such circumstances, family provides the context for holidays and vacations and demonstrates the enduring strength fammily tics ought to have.

Rebecca Collins's parents, who live only a few blocks from her, carc for her scven-ycar-old son after school and on evenings and wcekends when they are needed. Rebecca's lover, Sheila Ryan, has becn accepted into the family, and joins in large holiday celebrations and in summer vacations with Rebecca's brothers and their families. So docs Rebecca's former husband. Rebecca and Sheila have a circle of friends, including several Icsbian couples, but Rebccca emphasizes the cultural and recrcational facets of these relationships-going to concerts and out to dinner, talking about common interests-rather than the need for concrete or even emotional support. She gains a sensc of camaraderie from her fricnds, sharing fcelings with them about bcing lesbian, but says that she rarely asks them for anything substantial.

Paula Abrams, the mother of a son and daughter, shares almost everything with her mother. As we saw in Chapter 2, Paula's first impulse when she came out was to call her mother. Hcr mother was generally supportive, despite her concern about the stigma Paula 
might suffer, but she did not share the information with her husband; she decided on the spot that Paula should not come out to her father.

It is more common for lesbianism to create great strain in the family, but lesbian mothers who value close bonds and mutual aid with relatives work hard to overcome barriers to continuing involvement with their families. The arrangements they devise may require them to avoid discussion of their sexual orientation, keep their lovers and friends out of the kin network, and make othcr compromises out of consideration for their parents' and siblings' sensibilities.

Evelyn Brandon, who lives in a blue-collar suburban community with her lesbian lover and her three-month-old son, has had to tread a narrow line to maintain good relations with her family. Her father and his wife are fundamentalists, so even the fact that she had a baby out of wedlock has been a shock to them. She has not told her stepmother that she is a lesbian, but when her brothcr asked her directly, she acknowledged that she was. His reaction was not wholly positive, but Evelyn explains that the relationship is not in danger.

So even though he [doesn't] approve and he would rather I didn't, he's still $m y$ brother. And he'll stand by me. He's pretty much taken that stand also for the baby.

Shortly after Evelyn becamc pregnant she was laid off from her job, and found herself in a precarious economic position during her pregnancy. She moved in with her lover, but various bureaucratic delays with her insurance carrier compelled her to borrow money from her brother to cover her obstetrical expenses. She expects the insurance to reimburse her for them eventually, but she is still waiting for the money three months after the baby's birth.

Evelyn and her brother talk on the phone about once a week and visit together once or twice a month. She says they have a special bond because both of their parents have remarried several times since their divorce. She and her brother had a rather unsettled childhood, living sometimes with one parent and sometimes with the other, and still view their relationship as the only bit of stability they had during those years. Her brother not only has loaned her money but advises 
her on such things as how to organize her finances and how to select insurance. Though he has accepted her lesbianism, he has not told his wife about it; he feels that Evelyn's unwed pregnancy is about as much as she should have to absorb right now. Evelyn sees their rclationship as the most central family tie she has, and expects her son to have strong relations with his cousins, her brother's children. She has also cultivated a good relationship with the family of her baby's father. They have been generally supportive, accepting the baby as their grandchild even though their son has chosen to distance himself from Evelyn. Evelyn reccives AFIC but has not revealed the father's name because she wants to keep their relations cordial. Her idea is that the baby will eventually get to know his father, and their coming together will be easier if the state has not hounded him for child support.

Other mothers have found the business of maintaining connections with their families complicated. Rita García, a lesbian mother who lives with her lover, Jill Hacker, and her eight-year old son, Jim, in a working-class San Francisco neighborhood, finds that her arrangements with her parents require constant diplomacy. Rita comes from a close-knit Mexican-American family, and the only shadow on her happiness at having found Jill and come out as a lesbian has been their refusal to accept the situation. Their first reaction was such outrage that they considered supporting her husband's early claim for custody of Jim on the grounds that she was no longer a fit mother. In the actual divorce proceedings, however, Rita's husband failled to show interest in custody. As more information about Rita's marriage surfaced and the family learned that her husband had frequently abused her, they dropped their plans to support him; their opposition to her Iesbianism, however, has not abated.

The family's attitude was so hostile that Rita did not see her parents at all for about a year. She missed them constantly, often thinking of what they were doing at that moment. The situation was resolved when Rita's grandmother had major surgery. Rita had always been close to her grandmother and was the obvious choice when a family member was needed to handle daily nursing care. Rita's care of her grandmother after she returned home from the hospital reinstated her 


\section{[84] Lesbian Mothers}

in the family and reestablished a basis for mutual assistance. Her ties to her mother were also solidified during this time as she resumed her longstanding role of confidante. Rita says of her mother:

She leans on me a lot for support. I'm glad that she can, that I can help her when things are getting her down. When she can't take any more, she'll lean on me.

Rita's son, Jim, attends a Catholic school in her parents' neighborhood. She drops him off at their house every day on her way to work. Her mother makes breakfast for him before he walks to school. After school he returns to his grandmother's, plays with neighborhood children or does his homework, and eats dinner before Rita picks him up on her way home. This arrangement permits Rita to put in for as much overtime as possible at her downtown clerical job. On the occasions when Rita and Jill have evening plans, Jim spends the night with his grandparents.

Rita also depends on her father for advice and for practical assistance. Whenever something is troubling her, she talks with her father, and he regularly helps her with her car, changing the oil and taking care of other routine service. She is particularly close to her sister as well, though her sister is still very uncomfortable about her lesbianism. Nevertheless, Rita talks often on the phonc with her, discussing virtually any subject except her sexual orientation and her lover. Their children visit back and forth frequently, sometimes spending the weekend at Rita's house or her sister's. If Rita were going out of town and needed extended care for Jim, she says, she would ask her sister rather than her mother or lover to provide it. She feels it would be too much of a strain for her mother to take care of Jim for an extended period, and it never occurs to her that it would be suitable for her to leave him in Jill's care.

Rita's parents do not accept Jill as a family member. They have never visited her home (ostcnsibly because they think it's in a bad neighborhood), and Jill is never included in any sort of family occasion. On such holidays as Thanksgiving and Christmas, Jill visits her own family in Southern California while Rita and Jim celebrate with her family. 
The revelation of Deborah Cohen's lesbianism precipitated an angry confrontation with her parents, and for several weeks they had no direct communication with her. But before long, her mother and father contacted her, explaining that they could not endure a sustained separation.

It's real painful for them. They don't want to hear it. So most of the time I don't talk about it. . . But it's a very tight farnily and my mother says we can't disown you. We can be really sad and unhappy about what you're doing, and [feel] you are making a big mistake, but we love you and that's that.

Deborah sees her parents about once a week, sometimes for long visits, sometimes to pick up her daughter when they baby-sit for her. Though they have not reconciled themselves to her lesbianism and still argue with her about it at times, most of the time they stick to other topics of mutual interest: Judaism, the situation in the Middle East, Israel, and related political matters. They spend all Jewish holidays together and Deborah attends an Orthodox synogogue with her family. The ongoing strain over Deborah's sexual orientation reveals itself in visiting and baby-sitting patterns. Her mother feels that if they spent time in Deborah's home, they would somehow be condoning her lifestyle, so they visit Deborah only on her daughter's birthday. Besides providing child care virtually whenever Deborah needs it, her parents have provided the money to send her daughter to summer camp.

And I also do know that they're there. That's one thing that's really important. As much as they don't approve of what I'm doing, as much as they think it's a mistake, I have been real down and out, like with my past lover, my mother called one time and I was just crying. . . She asked me what was happening, and I could really let loose and let her see all my feelings. She was right there. When I'n really down, my mother is there. She does not judge me. It's the nomal everyday living she does her judging. . . I know they're there, if I ever really need anything, they're there. And that's good.

When mothers' ties with their relatives had been tenuous or stressful before the birth of their babies, their new situations may lead 
to surprising reversals. Maggie Walters, a lesbian mother with an eighteen-month-old daughter conceived through artificial insemination, discovered that becoming a mother suddenly changed her relationship with her own mother.

She gave me all the razz about it before I got pregnant, and then I got pregnant and she was instantly supportive. Never gave me any shit about $i t$. . I think because I was actually pregnant, you know. And that's serious. You don't put somebody down.

Maggie and her mother talk on the phone frequently, and her mother has loaned her money and has even suggested moving in together so that she could help Maggie with the baby. Before the baby was born her mother never offered her any kind of financial assistance.

Even when assistance is on a small scale, lesbian mothers may find the support of a parent essential. Anita Korman and her fourteenyear-old daughter live a few blocks away from her mother, who moved there from another state to be closer to her daughter and granddaughter. Anita and her mother spend a lot of time togethershopping, going to movies, eating out-though Anita suspects that her mother is still unhappy about her lesbianism. Her mother is quite critical, for instance, of women whose dress and demeanor seem to her to be "masculine," and she complains about the appearance of some of Anita's friends.

She says they look just like truck drivers and I say, Momma, they are truck drivers.

At the same time Anita does not hesitate to ask her mother for sirall loans and for other kinds of assistance.

She's real helpjul to me financially and she's loaned me money numerous times. Not that she has a lot of money, but if I need to borrow \$25 or \$50, she's right there. . . She's the one person that I really feel helped me to raise Imy daughter]. 
In recent years Anita's mother has become quite dependent on her daughter and granddaughter for social support. Years ago her mother provided support when Anita and her daughter were on their own; now the teenage daughter goes to visit her grandmother whenever she suspects she might be lonely. The grandmother moved to San Francisco only because Anita lived there, so she has few other social connections, as Anita is acutely aware.

Assistance from parents may require complicated and expensive arrangements. Margo Adler's parents fly to California from the East Coast (at their expense) for two weeks each year to take carc of her developmentally disabled child so that Margo can have a vacation. They are the only people Margo trusts to care for her difficult and demanding daughter.

Michelle O'Neill, who feared that her staunchly Catholic mother would never accept a grandchild conceived by artificial inscmination, is another lesbian who found that the birth of a grandchild improved her relationship with her family.

Since my son was bom, $m y$ relationship with $m y$ mother has improved greatl $y$, mostly on the level of relating to that I bave a child and she's a mother and now she's a grandmother and [he] is her only grandibild and she's very interested in him and stuff. So now our relationship is quite good and also I've matured and kind of gone through $m y$... radical phase.

Michclle is living on a very restricted budget while she attends nursing school, and her mother's support has been material as well as emotional. Her mother is fairly well off and has provided substantial amounts of money as well as a constant stream of baby clothes and other gifts. But probably most vital to Michelle is the fact that having a baby in this way and being a lesbian have not made her a pariah to her family; despitc her mother's initial anxicty that Michelle's "freaky" way of getting pregnant would cause her to be written up in a medical journal.

But then, after [my son] was born . . it has not made a difference at all-the way that I got pregnant or the fact that I'm a lesbian or that I'm a single mother. 


\section{[88] Lesbian Mothers}

She just is in love with her grandchild and it just doesn't make any difference to her anymore.

Ties to family and home are described as enduring, as characterized by both stability and continuity. Mothers emphasize that kinship connections compensate them for the uncertainties of other relationships, particularly those with lovers or husbands. We will see later that these are themes are prominent in their descriptions of their relations with their children as well, in no small measure because these relationships, like their links to other members of their families, are based on blood.

Bonnie Percira described her family and her home town:

I know that no matter what happens in this world, I can go back to that little place and it'll be the same, and I'll draw some security out of that.

The ability of some lesbian mothers to maintain meaningful relationships with their relatives appears to signify that their lives are still anchored in a unit called "the family." For these women, depriving their children of the opportunity to be part of what they conceive of as a family is a far more serious kind of deprivation than the more immediate economic limitations they experience. Their definitions of "family" are often revealed in their descriptions of holiday celebrations."

Irene Willoughby and Gerry Curtis, working-class lesbian mothers who live together with Gerry's four children and one grandchild, define "family" in terms of generations living together. Irene, who lost her two sons in a custody battle, feels particularly strongly that their home should provide a family for their friends and for neighborhood kids who don't get along with their parents. A recent test of their family's strength was the pregnancy of Gerry's fifteen-year-old daughter. She decided to keep the baby, and Gerry and Irene have assumed most of the child care. Both Irene and Gerry expect that they will continue to live with at least some of the kids for some time into the future. Irene puts it this way: 
See, I believe in generations living together. So that the young can learn from the old, and the old can leam from the young. Every day. We both believe in families.

This rather nostalgic concern with maintaining a sense of family is not always comfortably resolved. Marsha Lazarus, a lesbian mother who lives with her eight-year-old son in San Francisco, voices concern about how to provide her child with a "normal" childhood. She has only a tenuous relationship with her former husband, and the only blood relative available to her is her elderly father, who is quite involved with his grandson. She has a stormy relationship with a lover and doesn't expect it to continue for long. Most clearly because of the absence of a second parent in the household, Marsha defines herself as lacking a family, a situation she feels may be detrimental to her son's development. In her efforts to make up for this perceived deficit she has been extremely indulgent with Sean, and that strategy is now backfiring: the boy refuses to accept Marsha's lover into their household.

I guess part of it is that feeling I want him to have what I consider a normal childhood, and I don't want him to suffer because he has just a single parent in the house. . . I think maybe I've gone overboard.

But Marsha's preoccupation with the absence of a family from her life was not shared by many of the other lesbian mothers I spoke with. Most lesbian mothers seem to be able to adapt their notions of family to fit their actual circumstances better than some hetcrosexual mothers whose nostalgia for the more traditional family they once expected to have may overwhelm their efforts to define their own domestic situation as a meaningful social unit.

Claudia Hopkins, a heterosexual mother with one teenage daughter, has been divorced for thirteen years. Though she sees her divorce as a positive development in her life, the source of the first "freedom" she has experienced as an adult, she often feels that she has to compensate her daughter for the inadequacy of their family. These feelings are particularly intense when she plans holiday celebrations. Her efforts to include lots of friends seem "contrived" to her. 


\section{[90] Lesbian Mothers}

It feels like not a fanily, because you don't have the other part of the family that you're supposed to have. You don't have two parents, and you don't have other kids. Part of my script was always to have more childrem, so I nissed that. That's part of the way I feel, as If I's missing somebody. Who knows who, but I have all these pieces missing. And [my daughter] really likes to have a lot more people around, and large families, so she gets that with her father and his family, because his wife has a huge, extended fanily, who often get together.

Another heterosexual mother, Alison Kahn, is overwhelmed by regret whenever she plans outings or excursions with her seven-yearold daughter:

One just has this fantasy of what families are doing together, boating together, fishing together, and playing tennis, hiking together, and 1 think that as a single parent there is much less of an incentive to do that in a twososne.

The implication here, of course, is that the unit headed by a single mother is only a part of a "real" family. To many lesbian mothers, in contrast, the family consists of their parents (and sometimes their siblings). By shifting the framework for assessing their family status from the nuclear family or married couple across generations, they are able to sustain a sense of being part of a family constellation.

In adopting this broader concept of family, lesbian mothers are using a strategy well documented among female-headed households in a variety of cultures. Poor African-American women, for example, manipulate the boundaries of family units to cnlarge the pool of responsible adults in a world where marriage is an abstractly attractive goal but actual husbands are rare. ${ }^{7}$ Throughout societies where most families are headed by women we find lineal kinship being mobilized both to enhance the notion that a mother and her children are connected and to provide emotional and material support as they face difficult conditions. ${ }^{8}$ Mothers who emphasize their love for their blood kin often say there is no one else with whom they can speak frankly and that they know they can trust their relatives to keep their confidences because their love for them is real and unconditional. But as significant as the real solace and comfort mothers derive from these ties is the sense of connectedness that links with kin provide. 
Margo Adler, whose parents have been willing to come from the East Coast to take care of her daughter so that she can have a vacation, are a major source of emotional support for her as well.

There's just sonte sense that they care about me, that to nte is the most helpful. I can feel really miserable and everything, and I always feel like well, I could go to my parents' and ny mother will take care of me and cook for me and be glad I'm there.

Alice Molinari, a heterosexual mother who chose her current apartment because of its proximity to her parents, describes her close ties with her mother in strikingly parallel language. Her parents help her out with small amounts of moncy, give her rides, and watch her kids when she has to go out in the cvening. She reciprocates by doing errands for them downtown, and imagines that she will eventually move in with them. But her relationship with her parents, and especially with her mother, amounts to much more than the favors they exchange.

You know, your family can be a very safe haven for you, especially if you're loaded down with a lot of responsibilities. Lots of tintes, when you have responsibilities like that, a lot of dentands are made on you that you can't respond to the way you want. A lot of stress results, an awful lot. [My nother] is the kind of woinan that always ntakes ine feel as though I'n just the gyeatest thing that's ever happened in her life. I know that I an just like everybody else. . but she makes nte feel so special. There's a lot of love that she communicates. Sometimes I just bask in it.

Nostalgia and Adaptation

There is no doubt that a woman's homosexuality can cause severe conflicts between her and her family. Most women's narratives reveal a desire, and sometimes efforts of nearly heroic dimensions, to resolve these disputes or at lcast to defuse the situation.

The compromises some mothers make are rather poignant; others describe their relatives as growing more flexible over time, perhaps because of a commitment to maintain ties with the grandchildren. In 


\section{[92] Lesbian Mothers}

nearly all cases kinship offers lesbians a vital set of ideas about being connected, just as it does for heterosexual single mothers. As we have seen, links with "blood" relatives yield benefits: financial assistance, emotional support, and the like. But perhaps more important, ongoing viable relationships with members of the family of origin offer mothers a sense of continuity, a source of legitimacy for their own unconventional families. The efforts they make to sustain these ties are far out of proportion to the concrete value they provide; we must look elsewhere for their cultural significance.

Other anthropological accounts have also stressed the differential significance of kinship in the lives of women and men. Sylvia Yanagisako, for cxample, demonstrates the importance of womancentered kin networks in the ongoing operation of interactions between households; even though both men and women may derive benefits from these networks, women are the organizers of kinrclated activity, the "kin keepers" who keep track of family members' activities, implement arrangements for social events involving kin, and mobilize networks as the need arises. These instrumental activities are embedded in gender conventions, though their regularities are often obscured by their very informality. ${ }^{9}$

Anthropologists who have focused on the informal roles women have assumed in kinship systems, even under conditions that provide them with few avenues to direct influence, make similar observations. Margery Wolf offers perhaps the most arresting version of the pattern, appearing as it does in a culture that denies women virtually any formal recognition as social actors. Wolf shows that the behavior of Chinese villagers in Taiwan can be accounted for only if one assumes the existence of an ephemeral, but expericntially authentic entity - the "uterine family," a set of linkages and expectations that mothers establish with their children and that (unlike the named representations of Chinese patriarchy) dissolve upon the death of the mother. ${ }^{10}$ In like fashion, Micaela di Leonardo's depiction of ItalianAmerican kinship as "the female world of cards and holidays" casts kinship as "work" that women do, even in the absence of formal recognition, ${ }^{11}$

These approaches all accord with Jane Collier's proposal that the 
family be understood as a "political arena" in which women actively pursue particular goals, goals that do not always resonate with those of men. ${ }^{12}$ In framing women's kinship maneuvers as active strategies, however, Louise Lamphere reminds us that specific, consciously desired goals need not be demonstrated, but may be inferred from patterns of interaction as well as from the outcomes of particular kinds of behavior. ${ }^{13}$ But although Lamphere (writing about women factory workers) proposes distinguishing between "strategies of resistance" and "strategies of accommodation," the narratives offered by lesbian mothers point to less easily dichotomized strategies. At the same time that explicit or obvious goals are pursued through the elaboration and maintenance of kinship ties, other purposes, better understood as related to the "work" of constructing identity, are also served.

Lesbian mothers' continuing reliance on their biological kin may also be viewed as a symbolic strategy in the sense identified by David Schneider in American Kinship. As lesbian mothers speak of their ties with their children and their expectations for relationships between the children and their fathers, they partake of a system of meaning Schneider identified as "American kinship." These meanings are preeminently normative rather than necessarily grounded in behavior, and while ideas about biology abound in American kinship, Schneider views them as cultural artifacts. ${ }^{14}$ If creating a "meaningful social order" is a core problem for all participants in American for any other) culture, then formulating a satisfactory connection to key cultural domains may be even more pressing for self-consciously marginalized lesbian mothers.

Ongoing links with kin offer mothers a representation of the legitimacy and stability of the family. The wider social system continues to legitimate the marriage-based family as the authentic unit in which motherhood should occur. But neither lesbian mothers nor heterosexual single mothers are any longer part of such units, and while some heterosexual mothers may entertain thoughts or fantasies of returning to this system through remarriage, lesbian mothers find themselves wholly outside it. Thus they seek legitimation in the family defined by blood relations. Ongoing links with kin help them in 


\section{[94] Lesbian Mothers}

two ways: they connect the mother-child unit to a larger kinship grouping, making it more durable and resilient and offering continuity through time; and they validate consanguinity, rather than marriage, as a legitimate basis of family life. From this perspective, we can see that the importance of kin ties for mothers prefigures the anticipated importance of these ties in the future. As ties established through marriage become increasingly irrelevant-often as a result of the father's lack of commitment to the children-strong ties with the family of origin provide a model for those links the mother hopes to enhance in the long run. 